\title{
STOLICA APOSTOLSKA I GŁÓWNE PROBLEMY NARODÓW ZJEDNOCZONYCH W OKRESIE PONTYFIKATU JANA PAWŁA II
}

ABSTRACT La Santa Sede e i principali problemi delle Nazioni Unite nel periodo del pontificato di Giovanni Paolo II

Il tema della Santa Sede e dei problemi delle Nazioni Unite nel periodo del pontificato di Giovanni Paolo II è piuttosto ampio. Comprende infatti un periodo di vent'anni, durante il quale si sono verificati molti avvenimenti e cambiamenti politici e sociali in tutto il mondo. In questo lasso di tempo la Santa Sede ha mantenuto la sua presenza nella comunità internazionale in veste di osservatore all'assemblea dell'ONU. La rappresentanza diplomatica all'ONU opera in base alle regole degli insegnamenti sociali della Chiesa. Govanni Paolo II intendeva questi insegnamenti come una serie di cerchi concentrici: iniziando dalla persona umana per finire al mondo globalizzato. Per questo motivo, in presenza di dittature e regimi, la scienza sociale cattolica ha sviluppato, come antidoto, il concetto delle regole di sussidiarietà. Il secondo fondamento di sicurezza umana è il principio di solidarietà, una caratteristica per Giovanni Paolo II che visse 30 anni della sua vita in uno stato a regime comunista.

Venne eletto pontefice in un particolare momento storico, in cui si parlava molto di sicurezza mondiale. L'ONU e la comunità internazionale basavano questa sicurezza sui principi di cooperazione e non ingerenza, e proprio Giovanni Paolo II ha contribuito affinché questo concetto venisse ampliato anche alla sicurezza individuale e sociale.

Nel 1969 accettò l'invito dei paesi del Patto di Varsavia a prender parte alla conferenza di Helsinki. Il principio fondamentale della conferenza era semplice: la sicurezza si basa sulla parità di forze. La Santa Sede aveva un altro concetto di sicurezza, tendendo in considerazione piuttosto il bene comune della comunità, per la quale l'uso della forza è sempre fonte di distruzione. 
Quest'opera in seguito influenzò le azioni umanitarie, energicamente sostenute dal Vaticano.

Il contributo di Giovanni Paolo II alle riflessioni sui diritti dell'uomo è enorme. Sostenne la sua convinzione che esistono valori e principi non negoziabili. Il loro ambito e la loro applicabilità non può dipendere dalla volontà della maggioranza o di gruppi di pressione.

La Santa Sede conserva un concetto preciso e chiaro di persona umana, il quale è imprenscindibile dalla trascendenza e da Dio. Secondo Giovanni Paolo II e il Vaticano era ed è un punto fermo per le considerazioni e per le attività poste in essere dalla diplomazia; conserva un chiaro concetto di persona umana per rispondere alla domanda da dove veniamo e dove stiamo andando.

ABSTRACT The Holy See and the main problems of the United Nations during the course of John Paul II's pontificate

The subject of the Holy See and the problems of the United Nations during the course of John Paul II's pontificate is quite broad. It involves the period of twenty years which were rich in many events and political and social changes around the whole world. In this period the Holy See maintained its presence in the international community with the status of an observer at the forum of the UN. The diplomatic representation of the Holy See in the UN is based on the social teaching of the Church. John Paul II conceived of this teaching as a great system of concentric circles: a system whose first element is the human person and the final one - the globalized world. Due to this fact, the Catholic social teaching elaborated the concept of the principle of auxiliarity as an antidote for the period of dictatorships and regimes. The other foundation of human safety is the principle of solidarity. This principle was a peculiar feature of John Paul II who lived thirty years of his life in a country ruled by a communist regime.

He was chosen as the pope in an extraordinary moment of history when international security was a much-discussed subject. The UN and the international community saw the foundations of this security in the principle of collaboration and non-interference, and John Paul II contributed to the elaboration of this concept by emphasizing the security of the individual and of the society.

In 1969 the Vatican accepted an invitation from the countries of the Warsaw Pact to take part in the Helsinki Conference. The main concept of this conference was straightforward - security consists in the balance of power. The Holy See had a different concept of security, one that emphasized instead the common good of the community, the community to which the usage of force always brings destruction. These activities later influenced humanitarian actions, vigorously supported by the Vatican.

John Paul II's contribution to the contemplation of human rights is immense. He was true to his belief about the existence of such values and rules that are not negotiable. Their range and applicability cannot depend upon the will of the majority or pressure groups. The Holy See maintains clear and precise 
concept of the human person who may never be divorced from transcendence from God. According to John Paul II and the Vatican the human person was and continues to be the point of reference expressed in views and actions, visible in diplomacy. The clear concept of man is maintained in order to facilitate an answer to the question where we come from and where we are headed.

Słowa kluczowe: Stolica Apostolska, stosunki międzynarodowe, ONZ, Jan Paweł II, nauczanie papieskie, prawa człowieka

Key words: the Holy See, international relations, UN, John Paul II, papal teaching, human right

Parole chiavi: Santa Sede, relazioni internazionali, ONU, Giovanni Paolo II, magistero papale, diritti dell'uomo

$\mathrm{P}$ owierzony mi temat - Stolica Apostolska i główne problemy Narodów Zjednoczonych w okresie pontyfikatu Jana Pawła II - jest dość szeroki, obejmuje bowiem okres ponad dwudziestu lat, a do tego był to czas bogaty w wielkie wydarzenia oraz zmiany polityczne i społeczne, wystarczy wskazać przemiany symbolizowane przez „Solidarność” i upadek muru berlińskiego; przesunięcie geopolityczne z linii Wschód-Zachód na podział Północ-Południe; szybki wzrost ekonomiczny notowany w różnych regionach świata, wiążący się z powstaniem nowych potęg ekonomiczno-polityczno-militarnych; będącą poza kontrolą spekulację na rynkach finansowych wraz z kryzysem i recesją gospodarczą; postępującą polaryzację między bogatymi, ciągle rosnącymi w siłę, i ubogimi, ciągle popadającymi w większe ubóstwo; czas wielkich konferencji światowych, poświęconych sprawom rozwoju, praw ludzkich, kobiet, zaludnienia, zamieszkania, mniejszości, i ich wpływ na paradygmaty antropologiczne i społeczne; powrót na scenę polityczną religii, jako punktu odniesienia dla tożsamości; zjawisko terroryzmu i nowych form wojny, mającej coraz częściej charakter lokalny i cywilny; pilny, czasami wręcz dramatyczny, problem kryzysu ekologicznego i klimatycznego.

W tym kontekście Stolica Apostolska utrzymywała swoją dyskretną, pracowitą i skuteczną obecność we wspólnocie międzynarodowej na forum Organizacji Narodów Zjednoczonych w charakterze obserwatora.

Wieczorem w przeddzień mojego wyjazdu do Nowego Jorku, po tym jak 30 października 2002 r. zostałem mianowany obserwatorem Stolicy Apostolskiej, papież Jan Paweł II przyjął mnie na rozmowę na temat tego, czy byłaby stosowna zmiana statusu Stolicy Apostolskiej na forum ONZ: czy należałoby zachować status obserwatora, czy też stać się pełnoprawnym członkiem tej organizacji, czego oczekiwano z różnych stron. Nie chcąc zdradzić swojej decyzji, Ojciec Święty jasno podkreślił, że priorytetem Stolicy Apostolskiej jest wolność wypowiedzi oraz wolność i możliwie szeroka współpraca z państwami członkami ONZ na rzecz promocji pokoju i współpracy dla dobra 
wspólnego narodów: elementy, które wydawało się, że będzie można skuteczniej realizować przy statusie obserwatora.

W okresie, który rozciąga się od założenia organizacji aż do tzw. upadku muru berlińskiego, ONZ starała się utrzymywać pokój i współpracę między narodami na bazie równowagi między mocarstwami.

Jaka była optyka preferowana przez Jana Pawła II? Wkład przedstawicielstwa dyplomatycznego Stolicy Apostolskiej na forum ONZ opiera się na zasadach nauki społecznej Kościoła, a każdy z papieży daje swój specyficzny impuls, wyraża pragnienia, stawia szczególne akcenty odnośnie do tych ogólnych zasad kościelnej nauki społecznej.

Jan Paweł II rozumiał katolicką naukę społeczną jako wielki zespół kół koncentrycznych: w centrum jest osoba ludzka, ze swoją godnością i niezbywalnymi prawami; później idą koła oznaczające miejsca, w których człowiek się rozwija i wchodzi w relacje: rodzina, szkoła, praca, zdrowie, polityka i społeczność lokalna; potem następuje społeczność krajowa, a na końcu również międzynarodowa zglobalizowanego świata. Każde koło, każdy zakres: rodzina, społeczność lokalna, krajowa, światowa - zawsze musi być widziane w relacji do godności i praw osoby ludzkiej, która jest w centrum.

$\mathrm{Z}$ tego też powodu za czasów dyktatur i reżimów totalitarnych pierwszej połowy poprzedniego wieku katolicka nauka społeczna rozwinęła - jako antidotum - koncepcję zasady pomocniczości. Jan Paweł II widział ją jako zasadę bardzo pożyteczną dla obrony tożsamości i działań rodziny, społeczności lokalnych, ogniw pośrednich między obywatelem i państwem, narodów, a jeszcze ogólniej - dla jednostki, stojącej wobec absolutystycznych roszczeń rządów totalitarnych. Pomocniczość jest fundamentem bezpieczeństwa ludzkiego i środkiem przeciw totalitarnym wymaganiom grup będących u władzy. Bardzo znaczące w tym zakresie było przemówienie Jana Pawła II na temat praw narodów wygłoszone wobec Zgromadzenia Ogólnego Narodów Zjednoczonych w październiku $1995 \mathrm{r}$.

Drugim fundamentem bezpieczeństwa ludzkiego, rozwiniętym przez katolicką naukę społeczną, jest zasada solidarności. Jest ona charakterystyczną cechą nauczania Jana Pawła II i stanowi myśl przewodnią jego encyklik społecznych.

Jan Paweł II przeżył trzydzieści lat swojego kapłańskiego i biskupiego życia w państwie o reżimie komunistycznym. Dobrze wiedział, że paliwem dla marksistowskiej machiny jest walka klas, która w krótkim czasie doprowadziła do rozdarcia tkanki społecznej i ludzkiej w komunistycznych społeczeństwach. Podejrzenia, wzajemna nieufność, donosy, nienawiść między klasami społecznymi - to wszystko doprowadziło do rozbicia systemu od środka. Antidotum na tamtą filozofię życiową i na system komunistyczny nie były rozwiązania siłowe, dominacja militarna i brutalna walka. Musiało ono pochodzić z dołu, od samego społeczeństwa; musiało polegać na zmianie mentalności, na solidarności społecznej, która była czymś zgoła przeciwnym do walki klas.

Solidarność zakłada poszanowanie praw człowieka i promuje je wszystkie, zarówno wspólnotowe, jak i indywidualne, prawa obywatelskie, kulturowe, ekonomiczne i religijne. W kontekście solidarności społeczeństwo organizuje się wokół idei poszanowania praw człowieka oraz w oparciu o zasadę współuczestniczenia jednostki i grup; dystrybucja dobrobytu nie jest już oparta tylko na dostępności zasobów, ale dokonuje się 
w świetle zasady równorzędnej godności każdej osoby. Jan Paweł II w sposób otwarty i zdecydowany poparł ruch „Solidarności” w Polsce właśnie z tej racji, że widział w nim zasiew pokojowej rewolucji, zdolnej do budowania nowego porządku w świecie, bardziej sprawiedliwego i pewniejszego.

Papież Jan Paweł II został wybrany w szczególnym momencie historii. Wówczas dużo mówiło się o bezpieczeństwie światowym, właśnie dlatego, że było ono zagrożone. Organizacja Narodów Zjednoczonych i wspólnota międzynarodowa opierały bezpieczeństwo światowe na zasadzie współpracy i nieingerowania jednego państwa w sprawy wewnętrzne innego kraju. Jan Paweł II przyczynił się do pogłębienia koncepcji bezpieczeństwa człowieka, kładąc nacisk w międzynarodowej polityce bezpieczeństwa na jednostki i społeczności z uwzględnieniem ich fundamentalnych potrzeb, biorąc pod uwagę konieczność zapewnienia mieszkańcom Ziemi wolności od zagrożeń: braku bezpieczeństwa, głodu, biedy, chorób, przemocy, nierówności oraz kataklizmów humanitarnych i naturalnych.

W 1969 r. państwa Układu Warszawskiego, zaangażowane w tzw. proces odprężenia, przedstawiły propozycję zorganizowania konferencji dyplomatycznej, mającej na celu budowanie przyjaznych relacji między państwami europejskimi. Stolica Apostolska przyjęła zaproszenie do wzięcia udziału w takiej konferencji, przedstawione przez rząd Finlandii, jej gospodarza; początkowo nosiła ona nazwę ,konferencja helsińska”.

Koncepcja bezpieczeństwa, na której opierały się prace tej konferencji, była prosta: bezpieczeństwo zasadza się na równowadze sił. Była to taka sama idea, jak ta, która kilka lat wcześniej legła u podstaw procesu rozbrojenia atomowego. Stolica Apostolska miała inną koncepcję bezpieczeństwa. Nie chodzi tylko o prostą równowagę władzy, sił militarnych i ekonomicznych, która odstrasza i demotywuje do stosowania rozwiązań siłowych, ale jednak nie przekreśla zasady, że siła może być użyta w zależności od oceny sytuacji przez konkretne państwo. Koncepcja bezpieczeństwa powinna raczej uwzględniać dobro wspólne społeczności, dla których użycie siły, sięgnięcie po środki wojenne, obojętnie militarne, ekonomiczne, kulturowe czy cybernetyczne, jak mówimy dzisiaj, zawsze przynosi destrukcję.

Owoc tych prac streszcza się w tak zwanym Akcie końcowym Konferencji Bezpieczeństwa i Wspótpracy w Europie z Helsinek. Była w nim jednak pewna nowość, dla której Stolica Apostolska żywo uczestniczyła wraz z innymi państwami nad tymi pracami, zaznaczając swój specyficzny wkład. W dokumencie tym potwierdza się zasadę nieingerowania w sprawy wewnętrzne żadnego z państw, ale jednocześnie mówi się, że nie jest ona absolutna, lecz podlega ocenie, na ile konkretne państwo zapewnia ochronę podstawowych praw człowieka. Stąd też prawo do pełnej suwerenności nie może być parawanem dla naruszania innych praw, jak prawa obywatelskie, polityczne czy religijne.

W takim sformułowaniu można znaleźć zalążki podstawy do ingerencji humanitarnej, sformułowanej expressis verbis niewiele lat później, podczas wojny na Bałkanach (w byłej Jugosławii), oraz obowiązku ochrony, jako pojawiającej się normy prawa międzynarodowego. Za swojego pontyfikatu Jan Paweł II udzielił znaczącego poparcia etycznego dla prawa-obowiązku ingerencji humanitarnej, zwłaszcza przy okazji kryzysu w Kosowie (1999). 
Sposoby realizacji obowiązku interwencji humanitarnej popierane przez papieża dotyczyły przede wszystkim wytyczenia korytarzy humanitarnych, tworzenia mechanizmów weryfikacji sankcji międzynarodowych (realizacja nałożonych sankcji musi być monitorowana, aby nie dotykały one bardziej zwykłej ludności niż reżimów) oraz opieki nad osobami wysiedlonymi i uciekinierami. Jeśli zaś chodzi o zbrojną interwencję humanitarną ze strony wspólnoty międzynarodowej, można ją uznać za usprawiedliwioną jedynie w tych przypadkach, w których weryfikują się pozytywnie kryteria prawa międzynarodowego, pozwalające na użycie siły w celu obrony zgodnej z prawem.

I na zakończenie kilka słów na temat wkładu Jana Pawła II w refleksję nad prawami człowieka i ich aplikację. Jego wkładem na rzecz postępu i implementacji praw człowieka była ciągła refleksja intelektualna i moralna na temat kierunku zmian samego systemu praw człowieka. Niestety, w dzisiejszych czasach, zwłaszcza na Zachodzie, który jest kolebką praw człowieka, możemy zaobserwować niebezpieczną utratę sensu i znaczenia praw człowieka. Stają się one pustym słowem, ponieważ ich treść, aplikacja czy odnoszenie do różnych sytuacji społecznych zaczynają zależeć od konsensusu czy woli większości. Zależą one od siły poszczególnych jednostek, grup ekonomicznych lub ideologicznych.

Jan Paweł II podtrzymywał swoje przekonanie, że istnieją wartości i zasady, które nie podlegają negocjacjom. Ich zakres i stosowalność nie może zależeć od woli większości czy grup nacisku, lecz muszą być przyjęte i stosowane same przez się, jak np. prawo do życia, do wolności, do sprawiedliwości społecznej, do wolności religijnej. Religijno-moralny wymiar Kościoła skłania Stolicę Apostolską do zachowywania precyzyjnego i jasnego pojęcia osoby ludzkiej, która nigdy nie może być odłączona od transcendencji, od Boga. $Z$ różnych powodów ta jasna koncepcja antropologiczna jest często widziana jedynie jako znak zacofania intelektualnego i ludzkiego. Podczas gdy zarówno dla Jana Pawła II, jak i dla Stolicy Apostolskiej była ona i jest stałym punktem w poglądach i działaniach, obecnym również w dyplomacji; zachowuje jasną wizję człowieka, aby odpowiedzieć na pytanie, skąd przychodzimy i dokąd idziemy.

Ks. abp Celestino MIGLIORE - włoski duchowny katolicki, od 1980 r. dyplomata watykański, m.in. w Angoli, USA, Egipcie, a w latach 1989-1992 w Nuncjaturze Apostolskiej w Warszawie. Od 1992 r. specjalny wysłannik Stolicy Apostolskiej przy Radzie Europy w Strasburgu, a następnie od grudnia 1995 r. podsekretarz ds. relacji Stolicy Apostolskiej z państwami. W październiku 2002 r. wyniesiony do godności arcybiskupa i mianowany przez Jana Pawła II nuncjuszem apostolskim oraz stałym obserwatorem Stolicy Apostolskiej przy ONZ w Nowym Jorku. Od 30 czerwca 2010 r. nuncjusz apostolski w Polsce. 